\title{
Freshwater periphyton response to technical-grade and two commercial formulations of glyphosate
}

\author{
Daniela Gonzalez; Ángela B. Juárez ${ }^{23}$; C. Pamela Krug; ${ }^{4}$ Marina Santos ${ }^{5}$ \& M. \\ SOLANGE VERA ${ }^{16,1}$, \\ ${ }^{1}$ Universidad de Buenos Aires, Facultad de Ciencias Exactas y Naturales, Departamento de Ecología, Genética y Evolución. \\ ${ }^{2}$ Universidad de Buenos Aires, Facultad de Ciencias Exactas y Naturales, Departamento de Biodiversidad y Biología \\ Experimental. ${ }^{3}$ CONICET-Universidad de Buenos Aires, Instituto de Biodiversidad y Biología Experimental y Aplicada \\ (IBBEA). ${ }^{4}$ UNSAM, CONICET, Instituto de Ingeniería e Investigación Ambiental (3iA). ${ }^{5}$ Instituto Nacional de Tecnología \\ Industrial (INTI), San Martín. ${ }^{6}$ CONICET-Universidad de Buenos Aires, Instituto de Ecología, Genética y Evolución de \\ Buenos Aires (IEGEBA). Buenos Aires, Argentina.
}

\begin{abstract}
Aвstract. Glyphosate is the most widely used herbicide worldwide. It may reach water bodies and affect microbial communities. We compared the effects of two commercial formulations and technical-grade glyphosate on a freshwater periphytic community. A laboratory bioassay was carried out with four treatments: technicalgrade glyphosate acid, Glifosato II Atanor ${ }^{\circledR}$, Roundup $\mathrm{Max}^{\circledR}$, at a concentration of $3 \mathrm{mg}$ active ingredient/L, and Control. At 2, 5 and 9 days after herbicide application, pigments concentration, dry weight, ash-free dry weight, and periphytic algal density were determined. An increase of Cyanobacteria and a decrease of Chlorophyta and Bacillariophyta abundances were registered in all treatments with the herbicide. This effect was greater when Roundup $\mathrm{Max}^{\circledast}$ and Glifosato II Atanor ${ }^{\circledR}$ were added, and was lower with technical-grade glyphosate, suggesting that additives in the commercial formulations may enhance glyphosate effects.
\end{abstract}

[Keywords: periphytic community, herbicides, technical-grade glyphosate, Roundup Max ${ }^{\circledR}$, Glifosato II Atanor ${ }^{\circledR}$, microcosms]

\begin{abstract}
Resumen. Respuesta del perifiton de agua dulce al glifosato grado-técnico y dos formulados comerciales. El glifosato es el herbicida más utilizado a nivel mundial. Puede llegar a los cuerpos de agua y afectar a las comunidades microbianas. Comparamos los efectos del glifosato grado técnico y dos formulados comerciales sobre una comunidad perifítica de agua dulce. Se llevó a cabo un experimento de laboratorio con cuatro tratamientos: glifosato ácido grado técnico, Glifosato II Atanor ${ }^{\circledR}$, Roundup $\mathrm{Max}^{\circledR}$, a una concentración de $3 \mathrm{mg}$ de ingrediente activo/L, y un Control. A los 2, 5 y 9 días posteriores a la aplicación de los herbicidas se determinaron la concentración de pigmentos, peso seco, peso seco libre de cenizas y densidad algal del perifiton. Se registró un incremento de la abundancia de Cyanobacteria y una disminución de Chlorophyta y Bacillariophyta en todos los tratamientos con herbicida. Este efecto fue mayor con la adición de Roundup Max ${ }^{\circledR}$ y Glifosato II Atanor ${ }^{\circledR}$, y fue menor con glifosato grado técnico, sugiriendo que los aditivos en los formulados comerciales pueden intensificar los efectos del glifosato.
\end{abstract}

[Palabras clave: comunidad perifítica, herbicidas, glifosato grado técnico, Roundup Max ${ }^{\circledast}$, Glifosato II Atanor ${ }^{\circledast}$, microcosmos]

\section{INTRODUCTION}

Glyphosate (N-(phosphonomethyl)glycine) is a post-emergent, systemic, non-selective, broad-spectrum herbicide, that inhibits the shikimate pathway in plants, disrupting aromatic amino-acid biosynthesis, reducing proteins synthesis and growth and ultimately leading to cellular disruption and death (Duke 1988). The use of glyphosate in Argentina, since the introduction of glyphosate-resistant crops in 1996, has increased up to 182 million liters in 2013 (Aparicio et al. 2015). This herbicide may reach shallow water bodies adjacent to crop fields either by accidental or wind-borne drift of the herbicide spray

Editora asociada: María Diéguez and terrestrial runoff, or directly by washing the application equipment, tanks or pails in them (Carter 2000). In Argentina, a few studies have determined glyphosate concentrations in natural water bodies (Peruzzo et al. 2008; Castro Berman et al. 2018). For instance, Ronco et al. (2008) reported concentrations as high as $10.9 \mathrm{mg} / \mathrm{L}$ in El Pescado stream (Pampa Region, Buenos Aires).

Once in the aquatic system, glyphosate may affect non-target organisms. One of the methods for assessing effects of contaminants are conventional single-species toxicity tests, however, they typically ignore the effects of other abiotic factors and species identities and 
their interactions (Rohr et al. 2006). In contrast, community studies using experimental microcosms or mesocosms allow testing the impacts of toxicants in a more realistic setting while controlling other environmental variables (Magbanua et al. 2013).

Periphytic algae possess many attributes that make them ideal organisms to study the impacts of contaminants on freshwater ecosystems (Lowe and Pan 1996; Sabater and Admiral 2005): a) they are primarily autotrophic and occupy a pivotal position in ecosystems; b) they are sessile and cannot avoid pollutants through migration or other means; c) they have relatively short life cycles and respond rapidly to shifts in environmental conditions; d) representative samples of the periphytic community can be collected from small substratum surfaces because they are spatially compact; and e) periphyton integrates the influences of environmental conditions over long periods of time. The effect of glyphosate or its formulations on freshwater periphytic algae has been poorly studied, using unialgal cultures (Wood et al. 2016) and the entire community (Pérez et al. 2007; Vera et al. 2010, 2012; Magbanua et al. 2013). However, there are very few studies comparing the effects of the active ingredient and different formulations of glyphosate at the periphytic community level. Vera et al. (2014) reported a similar increase on the periphytic pigment content with $3 \mathrm{mg}$ of the active ingredient/L of technical-grade glyphosate and Glifosato Atanor $^{\circledR}$, suggesting that the additives of this commercial formulation would not increase the toxicity of glyphosate. It is relevant to evaluate the impacts that different formulations and the active ingredient may have on sessile communities such as periphyton, since they play an important role in ecological risk assessment and so far, this subject has not yet been fully investigated.

The aim of this study was to evaluate the differential effects of the technical-grade glyphosate acid and two commercial formulations, Glifosato II Atanor ${ }^{\circledR}$ and Roundup $\mathrm{Max}^{\circledR}$, on a periphytic community in laboratory microcosms. The response to this perturbation was studied through changes in biomass and algal groups' abundances using periphyton developed on artificial substrates. Our main hypothesis was that the impact of glyphosate formulations on periphyton is greater than that of the active ingredient.

\section{Materials and Methods}

On April 2015, before the start of the bioassay, clear polycarbonate substrata $\left(35.7 \pm 1.6 \mathrm{~cm}^{2}\right.$ each) were sub-superficially submerged in an outdoor artificial clear pool (3000 L) for colonization during 36 days, when a maximum periphytic biomass was achieved. The selected pool for periphyton colonization was the oligotrophic mesocosm used in Pizarro et al. (2016), with a consolidated community of microorganisms.

For the laboratory bioassay, a modified Bold's Basal Medium (BBM) was prepared using water of the same pool from which the periphyton was obtained. Pool water was first centrifuged in order to eliminate particulate material and organisms. Then, macro and micronutrients from BBM stocks (Bischoff and Bold 1963) were added and finally the culture medium was autoclaved.

Twelve transparent containers (microcosms) were filled with $2 \mathrm{~L}$ of modified BBM and distributed in a culture chamber under controlled conditions $\left(23 \pm 2{ }^{\circ} \mathrm{C}\right.$, photoperiod 12:12). Four treatments were randomly assigned to the microcosms (three replicates per treatment): control (C, without herbicide), technical-grade glyphosate acid (G, >95\% purity), Glifosato II Atanor ${ }^{\circledR}$ (A, 43.8\% w/v monopotasic salt), and Roundup $\operatorname{Max}^{\circledR}(\mathrm{R}$, $67.9 \% \mathrm{w} / \mathrm{w}$ monoammonium salt). In all cases a nominal glyphosate concentration of $3 \mathrm{mg}$ active ingredient (a.i.)/L was used. In each experimental container, 3 supports, with 5 colonized substrata each, were placed.

The samples (one support per microcosm and a water sample for glyphosate analysis) were taken at 2, 5 and 9 days from the herbicide application. Glyphosate concentrations were determined using high-performance liquid chromatography-mass spectrometry (HPLC / MS). The studies were performed on a Waters Quattro Premier XE spectrometer (Waters, Milford, MA, USA) equipped with a Waters 2695 binary pump. The HPLC separation was performed on a XTerra MS C18 column (Waters, Milford, MA, USA, $100 \times 2.1 \mathrm{~mm}, 3.5$ $\mu \mathrm{m})$. The mobile phase consisted of water: acetonitrile:formic acid (90:10:0.1, v/v/v). An isocratic flow rate of $0.3 \mathrm{~mL} / \mathrm{min}$ and a column temperature of $40{ }^{\circ} \mathrm{C}$ were applied. The mass instrument was operated in electrospray positive ion mode, the capillary voltage was kept at $3.0 \mathrm{kV}$, the cone voltage at $25 \mathrm{~V}$ and 
the source temperature at $150{ }^{\circ} \mathrm{C}$. Nitrogen was used for desolvation as well as the cone gas. The detection limit and quantification were 0.16 and $0.6 \mathrm{mg} / \mathrm{mL}$, respectively. The initial glyphosate concentrations were $2.9 \pm 0.12$ $\mathrm{mg} / \mathrm{L}$ for $\mathrm{G}$ and A treatments and $3.1 \pm 0.12$ $\mathrm{mg} / \mathrm{L}$ for $\mathrm{R}$ treatment, and no differences were observed throughout the experiment.

At each sampling date, the periphyton of each substratum was removed by means of a fine brush. Samples for algae identification were obtained from one substratum of each microcosm and the scraped material was preserved with $1 \%$ formaldehyde and analyzed under microscope $(1000 \mathrm{x})$. For the remaining analyses, the periphyton of 4 substrata from each microcosm was removed, resuspended in $15 \mathrm{~mL}$ of sterile pool water and divided into three aliquots. For the quantitative analysis of the algal fraction, one aliquot was preserved with $1 \%$ acidified Lugol's iodine solution. Counts were performed using the inverted microscope technique (Uthermöhl 1958) at 400 $x$, and the counting error $(<15 \%)$ was estimated according to Venrick (1978). Since the number of dead diatoms observed under the microscope was very high, dead diatom abundance was also taken into account. Other aliquot was used to determine dry weight (DW) and ashfree dry weight (AFDW) (APHA 2005). The third aliquot was used for spectrophotometric pigments quantification, after extraction with $90 \% \mathrm{v} / \mathrm{v}$ acetone. Chlorophyll $a$ (Chl $a), b$ (Chl $b)$, and $c(\mathrm{Chl} c)$ and total carotenes were determined according to Jeffrey and Humphrey (1975) and Torres et al. (2014), respectively. The autotrophic index (AI) was estimated as the AFDW/Chl $a$ ratio. All periphytic variables were expressed per unit area.

In order to reduce the number of variables, two Principal Component Analyses (PCA) were performed. In the first PCA, each sample was ordered with DW, AFDW, pigments (Chl $a, b$ and $c$ and total carotenes) and the AI as variables. In the second PCA, each sample was ordered using the algal groups' abundances: Chlorophyta, Cyanobacteria, Dinophyta and Bacillariophyta (dead + alive). In both PCA, the first component explained more than $25 \%$ than the second one, therefore only these first principal components (PC1) were used for further analyses. For each first component, variables with loadings on the eigenvector above 0.4 and significant correlations (Pearson correlation coefficients, $P<0.05)$ were considered as more tightly associated to the corresponding PC1 (Table 1).
Table 1. First component eigenvectors (E1) of the principal component analyses (PCA). Pearson correlation coefficients (Pcc) between original variables and the first component of the PCAs. Chlorophylls $a$ (Chl $a), b$ (Chl $b$ ) and $c(\mathrm{Chl} c)$, dry weight (DW), ash-free dry weight (AFDW) and autotrophic index (AI).

Tabla 1. Autovectores del primer componente (E1) de los análisis de componentes principales (PCA). Coeficientes de correlación de Pearson (Pcc) entre las variables originales y el primer componente de los PCAs. Clorofilas $a(\mathrm{Chl} a), b(\mathrm{Chl} b)$ y $c(\mathrm{Chl} c)$, peso seco (DW), peso seco libre de cenizas (AFDW) e índice autotrófico (AI).

\begin{tabular}{lcc}
\hline Variable & E1 & Pcc \\
\hline Periphytic biomass' PCA & & \\
Chl $a$ & $0.46 \#$ & $0.99^{*}$ \\
Chl $b$ & $0.45 \#$ & $0.97^{*}$ \\
Chl $c$ & $0.45 \#$ & $0.96^{*}$ \\
Total carotenes & $0.46 \#$ & $0.99^{*}$ \\
DW & 0.07 & 0.14 \\
AFDW & 0.04 & 0.08 \\
AI & $-0.40 \#$ & $-0.86^{*}$ \\
\hline Algal groups' PCA & & \\
Bacillariophyta & -0.25 & $-0.68^{*}$ \\
Cyanobacteria & $-0.68 \#$ & $-0.86^{*}$ \\
Chlorophyta & $0.69 \#$ & $0.84^{*}$ \\
Dinophyta & $<0.01$ & -0.01 \\
\hline \# = loadings above I 0.40 I & &
\end{tabular}

${ }^{*} P<0.001$

The PC1 when samples were ordered by periphytic biomass variables (PC1bp), the PC1 using the abundances of algal groups (PClag) and the dead diatoms percentage were modeled using a general linear mixed model (GLMM) with treatment (four levels) and time (three levels) as fixed effects factors and replicates as random factor. VarIdent was used with the time-by-treatment interaction as the modeling function given that homoscedasticity was fulfilled and had the lowest AIC value. DGC ( $\alpha=0.05)$ was used for post hoc multiple comparisons. Infostat (version 2014) was used to perform PCA and correlation analyses. R statistical software (version 3.12; R Development Core Team 2014) and glmm packages were applied for GLMM analyses and DGC comparisons (Knudson 2015).

\section{Results}

In the principal component analysis in which samples were ordered by the biomass variables, the first component explained $65.7 \%$ of the total variability, correlated positively with pigments (Chlorophylls $a, b$ and $c$ and total carotenes) and negatively with the autotrophic index (Table 1). The GLMM analysis of the samples scores on the first component (PC1bp) showed no significant differences due to the time-by-treatment interaction $(P>0.05)$, but there were significant differences between treatments $(\mathrm{F} 3=3.20, P=0.04)$ and times 
$(\mathrm{F} 2=51.36, P<0.0001)$. Comparing mean PC1bp score values for treatments, C and A showed significant differences with respect to $\mathrm{G}$ and $\mathrm{R}$. The treatments $\mathrm{C}$ and A presented higher values of pigments content and lower AI values than $G$ and $R$ (Figure 1a). Mean score values increased significantly through time (Figure $1 \mathrm{~b}$ ) suggesting a decrease in the autotrophic index and an increase in pigments during the experiment. Periphytic chlorophyll $a$ and AI averaged $0.058 \pm 0.021 \mu \mathrm{g} / \mathrm{cm}^{2}$ and $981 \pm 231$ at day 2 , and $0.124 \pm 0.008 \mu \mathrm{g} / \mathrm{cm}^{2}$ and $379 \pm 83$ at day 9 , respectively. The mean values of the different biomass variables for each treatment throughout the study period are shown in Table 2.

Total periphyton mean algal abundance increased in all treatments throughout

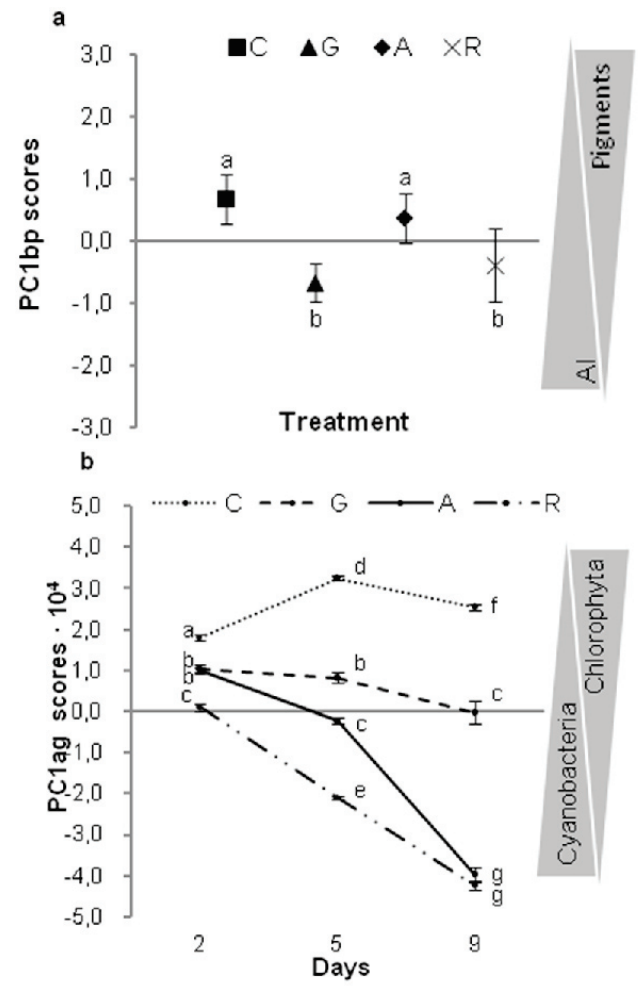

Figure 1. Mean values \pm SD of PC1bp scores (a) for each treatment, and (b) throughout the study period. Negative values are associated with higher autotrophic index (AI) values and positive values are associated with higher pigments content (see Table 1). Different letters indicate significant differences (DGC multiple comparisons, $P<0.05)$. Control $(\mathrm{C})$, technical-grade glyphosate $(\mathrm{G})$, Glifosato II Atanor ${ }^{\circledR}$ (A), Roundup Max ${ }^{\circledR}(\mathrm{R})$.

Figura 1. Promedio \pm DE de los valores de PC1bp (a) para cada tratamiento, y (b) a lo largo del período de estudio. Valores negativos se encuentran asociados con valores mayores del índice autotrófico (AI) y valores positivos con mayor contenido de pigmentos (ver Tabla 1). Letras distintas indican diferencias significativas (comparaciones múltiples DGC, $P<0.05)$. Control $(\mathrm{C})$, glifosato grado técnico (G), Glifosato II Atanor ${ }^{\circledR}(A)$, Roundup $\operatorname{Max}^{\circledast}(R)$.
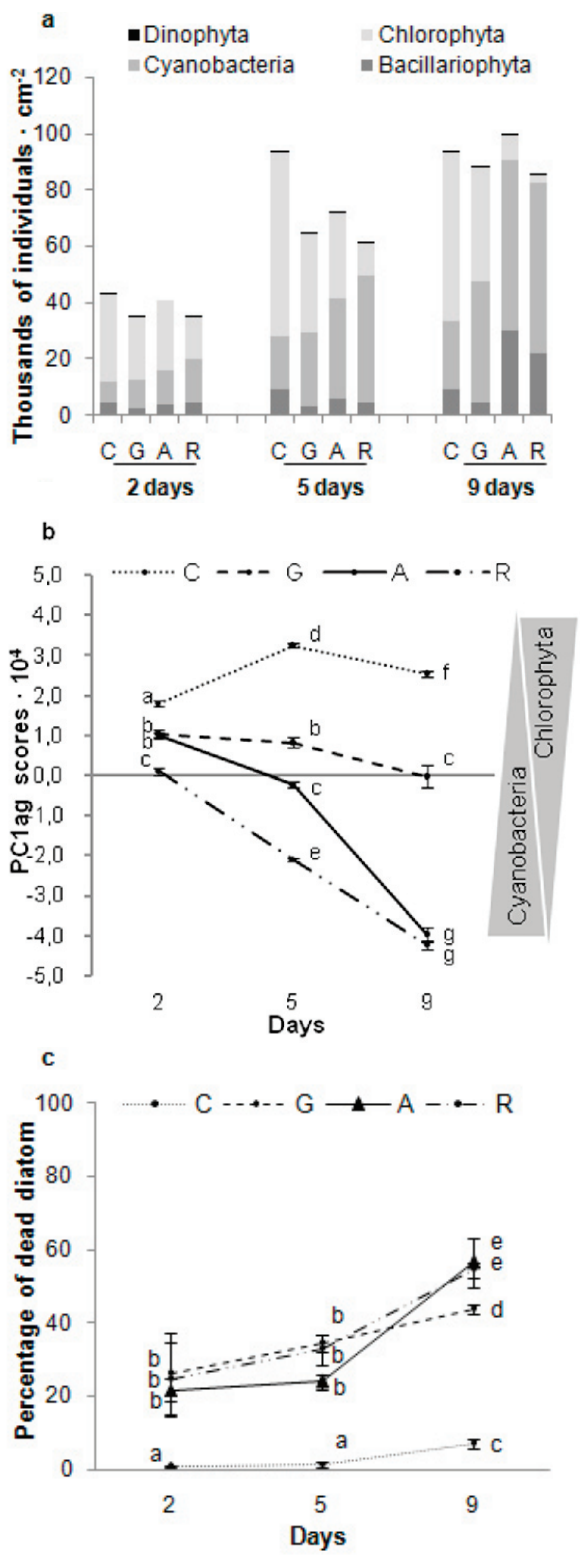

Figure 2. Mean values of (a) algal abundances by group, (b) PC1ag scores \pm SD. Negative values are associated with higher Cyanobacteria abundance and positive values with higher Chlorophyta abundance (see Table 1). (c) Mean values \pm SD of the percentage of dead diatoms/total diatoms for each treatment throughout the sampling period. Different letters indicate significant differences (DGC multiple comparisons, $P<0.05$ ). Control (C), technical-grade glyphosate (G), Glifosato II Atanor ${ }^{\circledR}$ (A), Roundup $\operatorname{Max}^{\oplus}(\mathrm{R})$.

Figura 2. Promedio de (a) las abundancias algales por grupo, (b) los valores de PC1ag $\pm \mathrm{DE}$. Valores negativos se encuentran asociados con abundancias mayores de Cyanobacteria y valores positivos con abundancias mayores de Chlorophyta (ver Tabla 1). (c) Valores promedio $\pm \mathrm{DE}$ del porcentaje de diatomeas muertas/ diatomeas totales para cada tratamiento a lo largo del período muestreado. Letras distintas indican diferencias significativas (comparaciones múltiples DGC, $P<0.05$ ). Control (C), glifosato grado técnico (G), Glifosato II Atanor $^{\circledR}(\mathrm{A})$, Roundup Max ${ }^{\circledR}(\mathrm{R})$. 
the study period, ranging from 35716 individuals $/ \mathrm{cm}^{2}$ at day 2 in $\mathrm{G}$ treatment to 100097 individuals $/ \mathrm{cm}^{2}$ at day 9 in the microcosms with Glifosato II Atanor ${ }^{\circledR}$. Mean abundances of each algal group in the different treatments are shown in Figure 2a. At the end of the study period, $\mathrm{R}$ and $\mathrm{A}$ treatments reached the highest diatom abundances ( 2 and 3 times higher than control values, respectively) and the lowest abundances of Chlorophyta $(\sim 21$ and 6 times lower than $C$, respectively) of the entire experiment. Cyanobacteria increased throughout the experiment in the four treatments, being always higher in microcosms containing herbicide, particularly in treatments with the commercial formulations (i.e., 2.5 times higher than $\mathrm{C}$ at the end of the bioassay). The dinoflagellates showed always the lowest abundances $\left(<1000\right.$ individuals $\left./ \mathrm{cm}^{2}\right)$.

The first component of the PCA, when samples were ordered by algal groups' abundances (PC1ag), explained $69.5 \%$ of the total variability and was positively correlated with Chlorophyta and negatively with Cyanobacteria abundances (Table 1). The GLMM analysis of the samples scores on the first component revealed significant differences due to the interaction between time and treatments $(\mathrm{F} 6=220.84, P<0.0001)$. Mean PC1ag scores of the control treatment were the highest over the course of the experiment, while the $\mathrm{R}$ mean scores were always the lowest and particularly negative at days 5 and
9 from the start of the bioassay (Figure 2b). The A treatment had positive scores at day 2 , and by the end of the experiment the scores were as negative as the microcosms with Roundup $\operatorname{Max}^{\circledR}$ (DGC comparison, $P>0.05$ ). The G treatment had positive scores at days 2 and 5 and near zero at day 9. These results suggest that treatment $C$ was associated with higher abundances of Chlorophyta throughout the experiment, and the $\mathrm{R}$ and $\mathrm{A}$ treatments were associated with higher abundances of Cyanobacteria (since day 5 and at day 9 from the herbicide application, respectively). In contrast, the $\mathrm{G}$ treatment showed a lower increase of Cyanobacteria and a lower decrease of green algae throughout the study period compared to treatments with commercial formulations (Figure 2a).

Two days after the beginning of the assay, the percentage of dead cells of Bacillariophyta was 29 times higher in glyphosate treatments compared to controls (Figure 2c). The proportion of dead diatoms to total diatoms showed significant differences due to time-bytreatment interaction ( $\mathrm{F} 6=4.86, P=0.003)$. Dead diatoms abundances were significantly higher in treatments with herbicide than in the control microcosms throughout the study (Figure 2c). No significant differences between glyphosate enriched treatments were registered on all sampling dates, except at day 9, when the microcosms with technical-grade glyphosate showed a lower percentage of dead diatoms than $\mathrm{A}$ and $\mathrm{R}$ treatments.

Table 2. Mean values $\pm \mathrm{SD}$ of chlorophylls $a(\mathrm{Chl} a), b(\mathrm{Chl} b)$ and $c(\mathrm{Chl} c)$, total carotenes, dry weight (DW), ash-free dry weight (AFDW) and autotrophic index (AI) for each treatment throughout the study period.

Tabla 2. Valores promedio \pm DE de clorofilas $a(\mathrm{Chl} a), b(\mathrm{Chl} b)$ y $c(\mathrm{Chl} c)$, carotenos totales, peso seco (DW), peso seco libre de cenizas (AFDW) e índice autotrófico (AI) para cada tratamiento a lo largo del período de estudio.

\begin{tabular}{|c|c|c|c|c|c|}
\hline & Day & Control & $\begin{array}{c}\text { Technical-grade } \\
\text { glyphosate }\end{array}$ & $\begin{array}{c}\text { Glifosato II } \\
\text { Atanor }^{\circledR}\end{array}$ & $\begin{array}{c}\text { Roundup } \\
\mathrm{Max}^{\circledast}\end{array}$ \\
\hline Chl $a\left(\mu \mathrm{g} / \mathrm{cm}^{2}\right)$ & $\begin{array}{l}2 \\
5 \\
9\end{array}$ & $\begin{array}{l}0.07 \pm 0.03 \\
0.12 \pm 0.01 \\
0.12 \pm 0.01\end{array}$ & $\begin{array}{l}0.04 \pm 0.01 \\
0.10 \pm 0.01 \\
0.12 \pm 0.01\end{array}$ & $\begin{array}{l}0.07 \pm 0.03 \\
0.11 \pm 0.01 \\
0.13 \pm 0.01\end{array}$ & $\begin{array}{l}0.06 \pm 0.01 \\
0.09 \pm 0.03 \\
0.12 \pm 0.01\end{array}$ \\
\hline Chl $b\left(\mu \mathrm{g} / \mathrm{cm}^{2}\right)$ & $\begin{array}{l}2 \\
5 \\
9\end{array}$ & $\begin{array}{l}0.02 \pm 0.01 \\
0.06 \pm 0.01 \\
0.09 \pm 0.01\end{array}$ & $\begin{array}{l}0.01 \pm 0.01 \\
0.04 \pm 0.01 \\
0.08 \pm 0.03\end{array}$ & $\begin{array}{l}0.02 \pm 0.01 \\
0.05 \pm 0.01 \\
0.09 \pm 0.01\end{array}$ & $\begin{array}{l}0.02 \pm 0.01 \\
0.04 \pm 0.03 \\
0.07 \pm 0.01\end{array}$ \\
\hline $\operatorname{Chl} c\left(\mu \mathrm{g} / \mathrm{cm}^{2}\right)$ & $\begin{array}{l}2 \\
5 \\
9\end{array}$ & $\begin{array}{l}0.01 \pm 0.01 \\
0.03 \pm 0.00 \\
0.03 \pm 0.00\end{array}$ & $\begin{array}{l}0.00 \pm 0.00 \\
0.01 \pm 0.01 \\
0.03 \pm 0.00\end{array}$ & $\begin{array}{l}0.01 \pm 0.01 \\
0.02 \pm 0.00 \\
0.03 \pm 0.01\end{array}$ & $\begin{array}{l}0.00 \pm 0.00 \\
0.01 \pm 0.01 \\
0.02 \pm 0.00\end{array}$ \\
\hline Total carotenes $\left(\mu \mathrm{g} / \mathrm{cm}^{2}\right)$ & $\begin{array}{l}2 \\
5 \\
9\end{array}$ & $\begin{array}{l}0.02 \pm 0.01 \\
0.05 \pm 0.00 \\
0.05 \pm 0.00\end{array}$ & $\begin{array}{l}0.01 \pm 0.00 \\
0.03 \pm 0.01 \\
0.04 \pm 0.00\end{array}$ & $\begin{array}{l}0.02 \pm 0.01 \\
0.04 \pm 0.00 \\
0.05 \pm 0.01\end{array}$ & $\begin{array}{l}0.02 \pm 0.00 \\
0.03 \pm 0.01 \\
0.04 \pm 0.00\end{array}$ \\
\hline $\mathrm{DW}\left(\mu \mathrm{g} / \mathrm{cm}^{2}\right)$ & $\begin{array}{l}2 \\
5 \\
9\end{array}$ & $\begin{array}{c}66.73 \pm 16.70 \\
76.07 \pm 8.55 \\
61.60 \pm 23.38\end{array}$ & $\begin{array}{l}58.60 \pm 8.85 \\
55.56 \pm 9.83 \\
73.73 \pm 2.14\end{array}$ & $\begin{array}{c}80.23 \pm 15.36 \\
56.47 \pm 3.52 \\
65.97 \pm 17.26\end{array}$ & $\begin{array}{c}77.57 \pm 4.18 \\
42.00 \pm 16.07 \\
55.07 \pm 4.92\end{array}$ \\
\hline $\operatorname{AFDW}\left(\mu \mathrm{g} / \mathrm{cm}^{2}\right)$ & $\begin{array}{l}2 \\
5 \\
9\end{array}$ & $\begin{array}{c}49.44 \pm 11.90 \\
50.37 \pm 3.70 \\
47.57 \pm 17.53\end{array}$ & $\begin{array}{l}44.92 \pm 5.11 \\
40.11 \pm 6.61 \\
54.10 \pm 2.14\end{array}$ & $\begin{array}{c}58.30 \pm 12.06 \\
46.18 \pm 1.40 \\
48.06 \pm 15.17\end{array}$ & $\begin{array}{l}60.31 \pm 4.60 \\
34.51 \pm 6.61 \\
39.18 \pm 6.10\end{array}$ \\
\hline AI & $\begin{array}{l}2 \\
5 \\
9 \\
\end{array}$ & $\begin{array}{c}788 \pm 178 \\
413 \pm 26 \\
383 \pm 127\end{array}$ & $\begin{array}{c}1203 \pm 286 \\
414 \pm 47 \\
447 \pm 13 \\
\end{array}$ & $\begin{array}{c}939 \pm 210 \\
425 \pm 40 \\
360 \pm 89 \\
\end{array}$ & $\begin{array}{l}993 \pm 60 \\
388 \pm 92 \\
326 \pm 43\end{array}$ \\
\hline
\end{tabular}




\section{Discussion}

The biomass of the autotrophic fraction of periphyton increased in the four treatments, as reflected by the increment of the pigment content and the decrease of the autotrophic index. This increase was probably promoted by the favorable conditions of the culture conditions, without limitation of light and nutrients. Microcosms with Glifosato II Atanor $^{\circledR}$ and without herbicide (control) showed a higher increment of the autotrophic fraction of the community than treatments with technical-grade glyphosate and Roundup $\mathrm{Max}^{\circledR}$. The minor increase in the periphytic biomass in $\mathrm{G}$ and $\mathrm{R}$ treatments could be due to the expected negative effect of glyphosate on the autotrophic fraction of the community since this herbicide inhibits the shikimate pathway in autotrophs, eventually leading to cellular disruption and death (Duke 1988). Both, the decrease and the increase in periphyton pigment concentrations after the addition of glyphosate-based herbicides have been reported. Moreover, the application of the same formulation of glyphosate, Roundup ${ }^{\circledR}$, has been found to generate both responses. Vera et al. (2010) observed lower pigment concentrations than controls in clear and turbid mesocosms using $8 \mathrm{mg} / \mathrm{L}$ of the herbicide. Instead an increase in periphytic chlorophyll $a$ in a natural tributary accidentally oversprayed with Roundup ${ }^{\circledR}$ was registered by Holtby and Baillie (1989). A single application of another commercial formulation, Glifosato Atanor ${ }^{\circledR}$, at a concentration of $\sim 3 \mathrm{mg} / \mathrm{L}$ induced a significant increase in periphyton Chl $a$ concentration both in outdoor (Vera et al. 2012) and indoor (Vera et al. 2014) microcosms. These contrasting responses of periphyton may result from interactions among different factors, such as the physical, chemical and morphometric characteristics of the water body, other communities, as well as the concentration and composition of the herbicide.

The biomass increase observed in the autotrophic fraction of periphyton was consistent with the higher algal abundance recorded in all treatments throughout the study period. However, the taxonomic composition of the periphytic algae showed variations among treatments. Cyanobacteria abundance increased throughout the experiment. Treatments with the addition of glyphosate formulations induced a higher increase of cyanobacteria compared with $G$ treatments, whereas the controls showed lower values at the end of the experiment. This implies that the additives of the commercial formulations used in the present assay could stimulate the development of cyanobacteria in freshwater ecosystems receiving inputs of the herbicide. The increase in the abundance of Cyanobacteria under glyphosate exposure had already been documented (e.g., Pérez et al. 2007; Vera et al. 2010, 2012). This pattern has been related with the overproduction of the 5enolpyruvylshikimate-3-phosphate synthase, the production of a glyphosate-tolerant enzyme (Powell et al. 1991), and the use of the phosphonate or the additives present in commercial formulations as phosphorus sources (Krogh et al. 2003; Lipok et al. 2007; Forlani et al. 2008).

Chlorophytes decreased their abundance in microcosms with Roundup Max ${ }^{\circledR}$ and Glifosato II Atanor ${ }^{\circledast}$ throughout the experiment. Instead, in $C$ and $G$ treatments this algal group increased its abundance, showing higher numbers in microcosms without herbicide. This suggests that glyphosate adversely affected Chlorophyta and the additives of the formulations enhanced this negative effect. Differential toxicity between a glyphosatebased commercial formulation, Roundup ${ }^{\circledR}$, and the active ingredient, glyphosate acid, on the green algae Selenastrum capricornutum in a laboratory assay was also reported by Tsui and Chu (2003).

Vera et al. (2010) found that Bacillariophyta was the most affected periphytic algal group, using the commercial formulation Roundup ${ }^{\circledR}$ at a concentration of $8 \mathrm{mg}$ a.i./L. In the present experiment, we also reported the presence of a large number of dead diatoms in the periphytic matrix after the exposure of the community to glyphosate-based herbicides, even using a concentration that was less than half of that used by Vera et al. (2010). This phenomenon was also recorded by other authors using different commercial formulations of glyphosate (Peterson et al. 1994; Tsui and Chu 2003; Pérez et al. 2007).

Most studies conducted with different autotrophic organisms in culture have shown that different glyphosate formulations have a higher toxicity than the active ingredient itself (Powell et al. 1991; Sáenz et al. 1997; Tsui and Chu 2003; Sáenz and Di Marzio 2009; Lipok et al. 2010). Nevertheless, a comparative research conducted with the entire periphytic community, suggested that Glifosato Atanor ${ }^{\circledR}$ would have similar toxicity than the technical- 
grade glyphosate (Vera et al. 2014). On the other hand, Gattás et al. (2016) reported that Chlorophyceae and Desmidiaceae were favored by both Roundup Max ${ }^{\circledR}$ and the active ingredient. In ourstudy, both glyphosate-based formulations showed higher toxicity than the technical-grade glyphosate for Chlorophyta and Bacillariophyta. In contrast, glyphosate promoted Cyanobacteria and the additives of commercial formulations enhanced their growth.

In agreement with Annett et al. (2014), there is a need for broader, community and ecosystem level investigations of a variety of glyphosatebased formulations to determine the extent of their impacts on aquatic ecosystems (see also Pérez et al. 2011). Studies with natural communities in microcosms are a useful tool to evaluate community-level effects. Microcosms provide controllability, replicability and facilitate the study of processes difficult to identify or understand in nature or field studies which are sometimes masked by natural variability. While the results obtained in microcosms experiments cannot be directly extrapolated to natural ecosystems, they provide clues to unravel processes occurring in natural aquatic ecosystems.

AcKnowledgements. We thank Universidad de Buenos Aires for the Scholarship granted to Daniela Gonzalez. This work was supported by ANPCyT PICT 1586 and UBACyT 20020130100248BA and UBACyT 20020150200116BA.

\section{REFERENCES}

American Publication Health Association. 2005. Standard methods for the examination of water and wastewater. 21st edition. Centennial Edition. APHA, American Water Works Association, Water Environmental Federation, Washington, DC, USA.

Annett, R., H. R. Habibi, and A. Hontela. 2014. Impact of glyphosate and glyphosate-based herbicides on the freshwater environment. J Appl Toxicol 34:458-479.

Aparicio, V., E. De Gerónimo, K. Hernández Guijarro, D. Pérez, R. Portocarrero, and C. Vidal. 2015. Los plaguicidas agregados al suelo y su destino en el ambiente. Instituto Nacional de Tecnología Agropecuaria (INTA), Buenos Aires, Argentina.

Bischoff, H. W., and H. C. Bold. 1963. Phycological Studies IV. Some Soil Algae from Enchanted Rock and Related Algal Species. Univ. Texas Publ. No 6318, USA.

Carter, A. 2000. How pesticides get into water - and proposed reduction measures. Pesticide Outlook 11:149-156.

Castro Berman, M., D. J. G. Marino, M. V. Quiroga, and H. Zagarese. 2018. Occurrence and levels of glyphosate and AMPA in shallow lakes from the Pampean and Patagonian regions of Argentina. Chemosphere 200:513-522.

Duke, S. O. 1988. Glyphosate. Pp. 1-58 in P. C. Kearney and D. D. Kaufman (eds.) Herbicides: Chemistry, Degradation and Mode of Action. Marcel Dekker, New York, USA.

Forlani, G., M. Pavan, M. Gramek, P. Kafarski, and J. Lipok. 2008. Biochemical bases for a widespread tolerance of cyanobacteria to the phosphonate herbicide glyphosate. Plant Cell Physiol 49:443-456.

Gattás, F., A. Vinocur, M. Graziano, M. dos Santos Afonso, H. Pizarro, and D. Cataldo. 2016. Differential impact of Limnoperna fortunei-herbicide interaction between Roundup $\mathrm{Max}^{\circledast}$ and glyphosate on freshwater microscopic communities. Environ Sci Pollut Res 23:18869-18882.

Holtby, L. B., and S. J. Baillie. 1989. Effects of the herbicide Roundup (glyphosate) on periphyton in Carnation Creek, British Columbia. Pp. 224-231 in P. E. Reynolds (ed.). Proceedings of the Carnation Creek Herbicide Workshop, Forestry Canada, Canada.

Jeffrey, S. W., and G. F. Humphrey. 1975. New spectrophotometric equations for determining chlorophylls $a, b, c 1$ and c2 in higher plants, algae and natural phytoplankton. Biochem Physiol Pflanz 167:191-194.

Knudson, C. 2015. glmm: generalized linear mixed models via Monte Carlo likelihood approximation. R package version 1(2).

Krogh, K. A., B. Halling-Sørensen, B. B. Mogensen, and K. V. Vejrup. 2003. Environmental properties and effects of nonionic surfactant adjuvants in pesticides: a review. Chemosphere 50:871-901.

Lipok, J., T. Owsiak, P. Młynarz, G. Forlani, and P. Kafarski. 2007. Phosphorus NMR as a tool to study mineralization of organophosphonates-the ability of Spirulina spp. to degrade glyphosate. Enzyme Microb Technol 41:286-291.

Lipok, J., H. Studnik, and S. Gruyaert. 2010. The toxicity of Roundup Max ${ }^{\circledR} 360$ SL formulation and its main constituents: glyphosate and isopropylamine towards non-target water photoautotrophs. Ecotoxicol Environ Saf 73:1681-1688.

Lowe, R. L., and Y. Pan. 1996. Benthic algal communities as biological monitors. Pp. 705-740 in R. J. Stevenson, M. L. Bothwell, and R. L. Lowe (eds.). Algal ecology. Freshwater benthic ecosystems. Academic Press, San Diego, California, USA.

Magbanua, F. S., C. R. Townsend, K. J. Hageman, K. Lange, G. Lear, G. D. Lewis, and C. D. Matthaei. 2013. Understanding the combined influence of fine sediment and glyphosate herbicide on stream periphyton communities. Water Res 47:5110-5120.

Pérez, G. L., A. Torremorell, P. Mugni, P. Rodríguez, M. S. Vera, M. Do Nascimento, L. Allende, J. Bustingorry, R. Escaray, M. Ferraro, I. Izaguirre, H. Pizarro, C. Bonetto, D. P. Morris, and H. Zagarese. 2007. Effects of the herbicide 
Roundup on freshwater microbial communities: a mesocosm study. Ecol Appl 17:2310-2322.

Pérez, G.L., M. S. Vera, and L. A. Miranda. 2011. Effects of herbicide glyphosate and glyphosate-based formulations on aquatic ecosystems. Pp. 343-368 in A. Kortekamp (ed.). Herbicides and environment. In Tech Open, Rijeka, Croatia.

Peruzzo, P. J., A. A. Porta, and A. E. Ronco. 2008. Levels of glyphosate in surface waters, sediments and soils associated with direct sowing soybean cultivation in north pampasic region of Argentina. Environ Pollut 156:61-66.

Peterson, H. G., G. Boutin, P. A. Martin, K. E. Freemark, N. J. Ruecker, and M. J. Moody. 1994. Aquatic phytotoxicity of 23 pesticides applied at expected environmental concentrations. Aquat Toxicol 28:275-292.

Pizarro, H., M. S. Vera, A. Vinocur, G. Pérez, M. Ferraro, R. J. Menéndez Helman, and M. dos Santos Afonso. 2016. Glyphosate input modifies microbial community structure in clear and turbid freshwater systems. Environ Sci Pollut Res 23:5143-5153.

Powell, H. A., N. W. Kerby, and P. Rowell. 1991. Natural tolerance of cyanobacteria to the herbicide glyphosate. New Phytol 119:421-426.

R Development Core Team. 2014. R: A language and environment for statistical computing. R Foundation for Statistical Computing, Vienna, Austria.

Rohr, J. R., J. L. Kerby, and A. Sih. 2006. Community ecology as a framework for predicting contaminant effects. Trends Ecol Evol 21:606-613.

Ronco, A. E., P. Carriquiriborde, G. S. Natale, M. L. Martin, H. Mugni, and C. Bonetto. 2008. Integrated approach for the assessment of biotech soybean pesticides impact on low order stream ecosystems of the Pampasic region. Pp. 209-239 in J. Chen and C. Guo (eds.). Ecosystem Ecology Research Trends. Nova Science Publishers, New York, USA.

Sabater, S., and W. Admiral. 2005. Periphyton as biological indicators in managed aquatic ecosystems. Pp. 159-78 in M. E. Azim, M. C. J. Verdegem, A. A. van Dam, and M. C. M. Beveridge (eds.). Periphyton: Ecology, exploitation and management. CABI Publishing, London, UK.

Sáenz, M. E., and W. D. Di Marzio. 2009. Ecotoxicidad del herbicida glifosato sobre cuatro algas clorofitas dulceacuícolas. Limnetica 28:149-158.

Sáenz, M. E., W. D. Di Marzio, J. L. Alberdi, and M. C. Tortorelli. 1997. Effects of technical grade and a commercial formulation of glyphosate on algal population growth. Bull Environ Contam Toxicol 59:638-644.

Torres, P. B., F. Chow, C. M. Furlan, and F. Mandelli. 2014. Standardization of a protocol to extract and analyze chlorophyll $a$ and carotenoids in Gracilaria tenuistipitata Var. Liui. Zhang and Xia (Rhodophyta). Braz J Oceanogr 62:57-63.

Tsui, M. T. K., and L. M. Chu. 2003. Aquatic toxicity of glyphosate-based formulations: comparison between different organisms and the effects of environmental factors. Chemosphere 52:1189-1197.

Utermöhl, H. 1958. Zur vervollkommnung der quantitativen Phytoplankton Methodik. MIH Verh Int Ver Limnol 9: 1-38.

Venrick, E. L. 1978. How many cells to count? Pp. 167-180 in A. Sournia (ed.). Phytoplankton manual. UNESCO, París, France.

Vera, M. S., L. Lagomarsino, M. Sylvester, G. L. Pérez, P. Rodríguez, H. Mugni, R. Sinistro, M. Ferraro, C. Bonetto, H. Zagarese, and H. Pizarro. 2010. New evidences of Roundup Max ${ }^{\circledR}$ (glyphosate formulation) impact on the periphyton community and the water quality of freshwater ecosystems. Ecotoxicology 19:713-719.

Vera, M. S., E. Di Fiori, L. Lagomarsino, R. Sinistro, R. Escaray, M. M. Iummato, A. Juárez, M. C. Ríos de Molina, G. Tell, and H. Pizarro. 2012. Direct and indirect effects of the glyphosate formulation Glifosato Atanor ${ }^{\circledR}$ on freshwater microbial communities. Ecotoxicology 21:1805-1816.

Vera, M. S., A. B. Juárez, and H. N. Pizarro. 2014. Comparative effects of technical-grade and a commercial formulation of glyphosate on the pigment content of periphytic algae. Bull of Environ Contam and Toxicol 93:399-404.

Wood, R. J., S. M. Mitrovic, R. P. Lima, and B. J. Kefford. 2016. How benthic diatoms within natural communities respond to eight common herbicides with different modes of action. Sci Total Environ 557-558:636-643. 